\title{
Aktivitas Komunikasi dalam Upacara Pemberkatan Pernikahan Agama Khonghucu (Kajian Studi Etnografi Komunikasi)
}

\author{
Monika Herliana \\ Universitas Jenderal Soedirman \\ monika.herliana@nusantarun.com
}

\begin{abstract}
This research is a qualitative descriptive study related to communication activities at the Confucian religious wedding ceremony in Jambi. The focus of this research is on communicative activities including situations, events, and actions of communication in wedding ceremonies with Ethnographic Communication studies. Data were obtained from observations, interviews, and supported by literature. The results of the analysis data show that during the Confucian ceremony there was a communicative situation which was conducive, sacred, familiar, and joyful. The process of marriage is sequentially described by communicative events from the beginning to the end of the procession. Communicative actions are characterized by verbal, non-verbal communication, and existing symbols. The three elements of the research results describe the communication activities which took place on the Confucian wedding ceremony. In addition, communication activities which occur have a close relationship with the concept of Confucian beliefs and teachings.
\end{abstract}

Keywords: communication event, Confucian, Marriage, Etnhography of Communication.

\section{Intisari}

Penelitian ini merupakan penelitian deskriptif kualitatif yang berkaitan dengan aktivitas komunikasi pada upacara pernikahan agama Khonghucu yang berada di Jambi. Fokus dari penelitian ini adalah pada aktivitas komunikatif antara lain situasi komunikasi, peristiwa komunikasi dan tindak komunikasi dalam upacara pernikahan dengan kajian Etnografi Komunikasi. Data diperoleh dari observasi, wawancara, dan didukung dengan studi pustaka. Hasil dari data analisis menunjukkan bahwa dalam upacara Khonghucu terjadi situasi komunikatif yang bersifat kondusif, sakral, keakraban, dan kegembiraan. Proses pernikahan secara berurutan digambarkan dengan peristiwa komunikatif dari awal hingga akhir prosesi. Tindakan komunikatif ditandai dengan komunikasi verbal, non verbal dan simbol-simbol yang ada. Tiga unsur hasil penelitian tersebut mendeskripsikan aktivitas komunikasi yang terjadi pada upacara pernikahan Khonghucu. Selain itu aktivitas komunikasi yang terjadi memiliki kaitan yang erat dengan konsep kepercayaan serta ajaran agama Khonghucu.

Kata kunci: Aktivitas komunikasi; khonghucu; upacara pemberkatan pernikahan; etnografi. komunikasi

\section{Pendahuluan}

Indonesia merupakan negara yang kaya akan ragam dan suku dimana setiap suku memiliki adat dan budaya yang berbeda-beda dan masih terjaga kelestariannya sampai saat ini. 
Khonghucu sebagai salah satu kepercayaan di Indonesia memiliki nilai-nilai kebudayaan yang khas sehingga hal tersebut dapat dijadikan sebagai aset kekayaan budaya Indonesia yang tak ternilai serta menjadi warisan bangsa yang sampai saat ini terus dilestarikan. Upacara pernikahan setiap kepercayaan memiliki ciri tersendiri sebagai bentuk ritual yang sakral serta untuk membedakan adat upacara dengan kepercayaan agama lain. perbedaan upacara pernikahan tersebut tergantung dengan kesepakatan-kesepakatan dan ajaran-ajaran nenek moyang kepercayaan masing-masing. Hal tersebut juga menjadi salah satu bagian aset kebudayaan yang berharga bagi penganutnya.

Indonesia menjadi salah satu Negara yang memiliki suku keturunan Tiong Hua terbesar di Asia. Masyarakat keturunan Tiong Hua yang ada di Indonesia dapat ditemui hampir di segala wilayah Indonesia. Sesuai dengan Keppres No 12 tahun 2014, bahasa Tiong Hua menjadi sebutan untuk Bahasa Mandarin yang merupakan bahasa nasional Republik Rakyat China atau Tiongkok. Selain Tiongkok, bahasa Tiong Hua juga digunakan oleh keturunan Tiong Hua yang berada di beberapa wilayah Asia lainnya, seperti Singapura, Taiwan, Malaysia, Hongkong, Jepang, Korea, dan Indonesia. Persebaran tersebut memeberikan pengaruh terhadap kegiatan ekonomi, politik, soaial-budaya bagi wilayah yang didatangi.

Masyarakat etnis keturunan Tiong Hua yang datang sebelum abad ke 19 membawa banyak pengaruh terhadap Indonesia (Karsono 2011). Hubungan perdagangan yang terjalin membuat banyak orang Tiong Hua datang dan menikah dengan masyarakat pribumi. Khonghucu sebagai salah satu kepercayaan yang turut serta dibawa merekapun berkembang pesat di Indonesia.

Dalam perkembangannya, kepercayaan yang dianut oleh sebagian besar etnis Tiong Hua di Indonesia dikenal dengan nama Tri Dharma, yaitu ajaran Buddha, Taoisme, dan Konfusianisme. Salah satu kepercayaan yang dianut oleh mayoritas masyarakat Tiong Hua di Indonesia adalah Konfusianism. Agama Konfusius atau Khonghucu atau Konfusianisme merupakan ajaran Kong zi, salah satu filsuf terkenal yang berasal dari daratan Tiongkok. Walaupun jauh dari negara asalnya, Tiongkok, namun penganut agama Khonghucu tetap memegang teguh ajaran dan tetap melaksanakan aktivitas keagamaan sesuai dengan ajaran Kong Zi. Salah satu masyarakat penganut agama Khonghucu berada di provinsi Jambi. Mereka masih memegang erat adat istiadat dan ajaran Khonghucu seperti upacara pemberkatan pernikahan agama Khonghucu (UPPAK). 
Pernikahan merupakan proses yang sakral dalam kehidupan manusia. Selain secara adat setempat, pernikahan juga harus sesuai dengan aturan hukum yang berlaku di Negara tersebut, termasuk di Indonesia. Undang-undang tentang pernikahan tercantum dalam UU Nomor 1 Tahun 1974 pasal 7 tentang pernikahan. Pernikahan yang diselenggarakan, dicatat pada kantor catatan sipil. Hal ini dilakukan untuk pengesahan proses pernikahan secara hukum. Setelah itu upacara pernikahan dapat dilangsungkan secara adat, dengan tata upacara yang berlaku dalam masyarakat tertentu. Sama seperti halnya agama Khonghucu. Setelah secara hukum pernikahan dinilai sah, maka upacara pernikahan dapat dilakukan berdasarkan adat-istiadat yang berlaku.

Pernikahan adat Tiong Hua umat Khonghucu saat sekarang ini sangat jarang ditemui, adapun pernikahan saat ini terselenggara sudah mengalami beberapa perubahan dengan tidak merubah makna sakral dari kepercayaan Khonghucu. Di Jambi, UPPAK dapat diselenggarakan di tempat-tempat yang telah dipilih dan disepakati oleh keluarga kedua mempelai. UPPAK tersebut dapat dilakukan di Klenteng ataupun di sekretariat MAKIN (Majelis Khonghucu Indonesia). Ini menjadi objek kajian yang sangat menarik, mengingat Klenteng juga menjadi tempat ibadah tidak hanya agama Khonghucu saja, melainkan tempat ibadah agama Budha dan Taoisme. Dalam penelitian ini, upacara pernikahan dilakukan di dua tempat sekaligus, pertama di sekretariat MAKIN Sai Che Tian Jambi, kedua di Klenteng. Obyek pnelitian ini adalah prosesi UPPAK yang dilaksanakan oleh kedua mempelai yang merupakan keturunan Tiongkok dan bertempat tinggal di Provinsi Jambi.

Pada penelitian ini upacara pernikahan akan dikhususkan pada tahap pemberkatan pernikahan. Penelitian yang dilakukan oleh penulis, bukanlah penelitian yang benar-benar baru di bidang etnografi komunikasi khususnya penelitian pada aktivitas komunikasi pada upacara pernikahan, namun penulis mencari celah sehingga penelitian ini memiliki perbedaan dari penelitian sebelumnya. Penelitian-penelitian sebelumnya yang dilakukan oleh para peneliti sebelumnya adalah sebagai berikut.

Penelitian mengenai etnografi komunikasi pada sebuah tradisi bukanlah penelitian yang baru. Terdapat banyak penelitian-penelitian terdahulu yang mengkaji etnografi pada sebuah adat dan tradisi suatu masyarakat tertentu. Berikut ini penelitian-penelitian terdahulu yang berkaitan dengan penelitian ini antara lain yaitu: Mufidah (2017) melakukan penelitian tentang UPPAK di kota Surakarta menggunakan teori antropologi, 
Hastika, dkk (2016) mengkaji tentang pernikahan antara etnis Jawa dengan etnis Lembak, Marta (2017), Zannah (2009), Annisa (2015), Maryati (2017), Widodo dan Urafa (2013), Setiawati dan Priyanto (2015), Rifa'i (2017), Ginting, dkk (2017), Sirait dan Hidayat (2015), Martvertnad (2016) mengkaji teori etnografi komunikasi dengan objek kajian berupa tradisi yang berbeda-beda. Penelitian-penelitian terdahulu tersebut, peneliti belum menemukan penelitian yang memfokuskan kajiannya pada upacara pemberkatan pernikahan agama Khonghucu menggunakan teori etnografi komunikasi. Oleh karena itu, peneliti tertarik untuk mengamati bagaimana aktivitas komunikasi yang terdapat pada UPPAK di Provinsi Jambi.

Etnografi komunikasi menjadi salah satu cabang ilmu antropologi yang berfokus pada komunikasi yang mengandung nilai-nilai dalam masyarakat. Pada 1964, istilah etnografi komunikasi diperkenalkan oleh Hymes, selanjutnya pada tahun 1972, Hymes dan Gumperz menggunakan istilah etnografi berbicara (Hymes 1972). Dengan demikian, makna dari cabang ilmu ini adalah mengacu pada aktivitas orang dalam berbicara pada saat melakukan interaksi sosial dengan orang lain. Penggunaan bahasa dalam komunikasi sangat erat kaitannya dengan budaya, maka dari itu, peneliti lebih berfokus pada ujaran yang diungkapkan oleh penutur (Kuswarno 2007). Konsep kompetensi komunikatif diungkapkan oleh Hymes untuk menandai seseorang yang tidak hanya berkompeten pada tuturan, namun juga pada aturan konvensi sosial-budaya yang berlaku di dalam komunitasnya.

Selain Hymes dan Gumperz, tokoh yang mengungkapkan teori tentang Etnografi komunikasi adalah Saville-Troike. Syarat-syarat yang termasuk ke dalam kompetansi komunikatif yakni, aturan komunikasi yang bersifat komunikatif maupun sosio-linguistik; aturan interaksi; kaidah budaya; pengetahuan tentang event komunikasi; dan proses interaksi (Saville-Troike 2008). Dalam perkembangannya konsep yang diungkapkan oleh Hymes tidak hanya memperdulikan tentang komponen tuturan, namun Hymes mengungkapkan bahwa tuturan itu juga harus menaati kebiasaan adat-istiadat yang ada dalam masyarakat tersebut (Hymes 1967).

Penelitian yang berkaitan dengan etnografi komunikasi pada umumnya menggunakan metode penelitian kualitatif agar dapat memahami objek kajian etnografi. Penelitian aktivitas komunikasi dalam upacara pernikahan, manusia memahami pengalaman melalui makna-makna yang ditemukan dalam komunitas, dan bahasa 
merupakan bagian yang penting dalam kehidupan sosial . Aktivitas komunikasi menjadi salah satu obyek penelitian etnografi komunikasi. Penulis dalam mengidentifikasi masyarakat tutur yang memiliki suatu variasi linguistik tertentu. Tahap selanjutnya adalah mengidentifikasi aktivitas komunikasi atau mengidentifikasi peristiwa komunikasi. Untuk mengidentifikasi aktivitas komunikasi tersebut, diperlukan komponen untuk memahaminya. Hymes mengungkapkan tiga unit dasar yang digunakan untuk mendeskripsikan aktivitas komunikasi tersebut yang terdiri dari situasi komunikatif, peristiwa komunikatif, dan tindak komunikatif. Berikut ini penjelasan singkat tiga unit dasar untuk menganalisis aktivitas komunikatif.

Pertama, Situasi komunikatif berkaitan dengan konteks terjadinya komunikasi. Kegiatan-kegiatan yang berbeda dapat memiliki situasi yang sama apabila dilaksanakan di lokasi yang sama. Hal tersebut seperti sudut jalan yang sibuk di siang hari akan memiliki kondisi yang berbeda dengan sudut jalan pada malam hari (Hymes 2012).

Kedua, peristiwa komunikatif berkaitan dengan komponen-komponen yang terdapat pada sebuah peristiwa komunikatif. Hal ini merupakan unit dasar yang digunakan untuk mendeskripsikan sebuah peristiwa sehingga dapat mengetahui pola komunikasi yang terbentuk pada sebuah peristiwa (Kac, Gumperz, and Hymes 2006). Menurut Hymes terdapat delapan komponen komunikasi yang dapat digunakan untuk menganalisis peristiwa komunikatif yang disingkat menjadi SPEAKING yang terdiri dari:

a. Situation berkenaan dengan setting dan scene. setting dapat berupa dengan waktu dan tempat tutur berlangsung, sedangkan scene mengacu pada situasi tempat dan waktu situasi psikologis pembicaraan.

b. Participant berkaitan pada pihak pihak yang terlibat dalam pertuturan. Pihak-pihak tersebut dapat berupa pengirim, penerima, penutur, dan mitra tutur.

c. Ends merujuk pada maksud dan tujuan sebuah komunikasi.

d. Act sequence berkaitan dengan rangkaian tindakan komunikasi yang didalamnya terdapat bentuk pesan dan isi pesan komunikatif yang ingin disampaikan.

e. Key mengacu pada nada, cara, dan semangat bagaimana pesan tersebut disampaikan. Ungkapan tersebut bisa disampaikan dengan cara senang hati, serius, singkat, sombong, mengejek, dan sebagainya, atau juga menggunakan gerak tubuh dan isyarat. 
f. Instrument mengacu pada jalur bahasa dan kode ujaran yang digunakan seperti bahasa lisan, tulisan, gerakan, dan lain sebagainya.

g. Norms mengacu pada norma atau aturan dalam berinteraksi dan juga mengacu pada penafsiran terhadap ujaran dari lawan bicara seperti menginterupsi, bertanya, menjawab, dan sebagainya.

h. Genre, mengacu pada jenis bentuk penyampaian seperti narasi, puisi, pepatah, doa, dan sebagainya (Hymes, 1994: 37 dalam Helmi Akbar, 2010:41).

Ketiga, Tindak komunikatif (Communicative Act), merupakan fungsi interaksi tunggal berupa pernyataan, perintah, permohonan, dan perilaku verbal. Dalam kondisi komunikasi, perilaku manusiaa yang tidak melakukan kegiatan apapun termasuk kedalam tindak komunikasi konvensional. Contoh tindak komunikatif adalah bertanya, memerintah, memohon, bersyukur, dan lain sebagainya.

Dengan memahami unit diskrit aktivitas diatas, menggambarkan bahwa aktivitas komunikasi dalam etnografi komunikasi tergantung dengan komunikasi, pesan, komunikator dan efek yang terjadi dalam komunitas. Aktivitas komunikasi yang terjadi merupakan peristiwa yang melibatkan tindak tutur dalam suatu lingkungan komunitas.

Berdasarkan alasan-alasan tersebut, penulis merumuskan permasalahan "Bagaimana aktivitas yang terjadi pada Upacara Pemberkatan Pernikahan Agama Khonghucu?" dan "Bagaimana bentuk dan fungsi tindak tutur yang terjadi pada Upacara Pemberkatan Pernikahan Agama Khonghucu?" Dua rumusan masalah tersebut bertujuan untuk mendeskripsikan aktivitas komunikatif dan mendeskripsikan bentuk serta fungsi tindak tutur yang terdapat pada upacara pemberkatan pernikahan agama Khonghucu.

\section{Metode Penelitian}

Penelitian ini merupakan penelitian deskriptif kualitatif karena penelitian digunakan untuk meneliti pada kondisi objek alamiah (Sugiyono 2016). Fokus penelitian ini menghasilkan data deskriptif yaitu data tertulis ataupun lisan dari pihak yang terlibat dari suatu peristiwa dan menimbulkan perilaku yang dapat diamati. Selain itu, fokus kajian etnografi komunikasi adalah melihat pola komunikasi yang terbentuk pada sebuah peristiwa sehingga penelitian ini akan menggambarkan atau mendeskripsikan, menganalisis, dan menjelaskan secara rinci rangkaian upacara pemberkatan pernikahan umat Khonghucu. 
Sumber data pada peneilitian ini adalah interaksi sosial yang terdapat pada UPPAK. Terdapat tiga data pada penelitian ini yaitu data primer atau data utama yang didaptkan menggunakan teknik observasi non-partisipasi yaitu data yang diperoleh dari pengamatan secara langsung oleh penulis, proses tersebut berupa peristiwa komunikasi yang terjadi pada saat ritual upacara pernikahan yang diselenggarakan di sekertariat MAKIN dan Klenteng. Data sekunder atau data tambahan diperoleh dengan teknik wawancara mendalam kepada masyarakat etnis Tiong Hua beragama Khonghucu yang pernah mengikuti upacara pernikahan agama Khonghucu dan data berupa informasi dari tokoh agama dan para pengamat kebudayaan Tiong Hua yang memahami tentang upacara pernikahan umat Khonghucu. Dalam penelitian ini, data diperoleh dalam situasi formal maupun informal pada saat terselenggaranya upacara pernikahan. Setelah data didapatkan, metode selanjutnya adalah menganalisis data menggunakan teori etnografi komunikasi beserta delapan komponen komunikasi Hymes yang disingkat menjadi SPEAKING (Hymes 1964) untuk mengidentifikasi pola komunikasi yang terjadi pada upacara pemberkatan pernikahan umat Khonghucu.

\section{Hasil dan Pembahasan}

Upacara pemberkatan dipimpin oleh Zhiji. Zhiji merupakan seseorang yang memimpin upacara pemberkatan pernikahan yang bertuga memandu jalannya prosesi pernikahan dari awal tiba di klenteng sampai selesai. Upacara pernikahan yang terselenggara pada hari Sabtu 11 November 2017 bertempat di MAKIN (Majelis Khonghucu Indonesia) Jambi dan di Klenteng. Berikut ini hasil penelitian yang berhubungan dengan tiga unit dasar yang dapat menggambarakan aktivitas komunikasi yang terjadi saat upacara pemberkatan pernikahan Khonghucu.

\section{Situasi Komunikatif (Communicative Situation)}

Situasi merupakan gambaran keadaan suatu peristiwa. Situasi dalam etnografi komunikasi mengacu pada konteks terjadinya suatu peristiwa. Situasi komunikatif memiliki maksud untuk menggambarakan bagaimana keadaan suatu peristiwa seperti tempat pelaksanaan acara, pakaian yang digunakan, pemilihan hari, pihak yang terlibat, suasana kegiatan, dan lain sebagainya.

Pada penelitian UPPAK ini, terdapat dua tempat yang dikunjungi. Dalam prosesi awal dan pemberkatan, prosesi tersebut bertempat di Sekretariat MAKIN Jambi Sai Che 
Tian. Prosesi awal meliputi persiapan kedua mempelai beserta keluarga yang mendampingi. Dalam ritual upacara pemberkatan, dimulai dari ambang pintu sebelum masuk ke dalam ruangan peribadatan. Sepasang pengantin mengenakan baju pengantin dan berkalung kain panjang berwarna kuning sebagai tanda penghormatan karena berada di tempat yang suci. Demikian juga dengan seluruh keluarga kedua mempelai, mereka semua mengenakan kain kuning yang dikalungkan di bagian leher. Rangkaian acara selanjutnya adalah prosesei pemberkatan. Setelah prosesi pemberkatan, kedua mempelai dan keluarga menuju ke klenteng untuk sembahyang/penghormatan kepada dewa-dewa yang berada di klenteng. Pada prosesi pemberkatan, berada di aula sekertariat MAKIN kedua mempelai berhadapan dengan altar Nabi Kongzi. Dengan pakaian pengantin pria berwarna hitam dan pengantin wanita berwarna putih, keduanya mengikuti prosesi pemberkatan dengan khidmat dengan dituntun oleh Zhiji. Tidak ada iringan lonceng atau benda yang lain sehingga situasi pemberkatan berjalan dengan tenang, sakral, dan khusu', serta memiliki unsur kebahagiaan, kegembiraan, dan kental dengan unsur Tionghoa dengan altar serta Hio (dupa). Tidak hanya kedua mempelai yang menunjukkan ekspresi kebahagiaan, namun orang tua dan seluruh keluarga pun merasakan demikian.

\section{Peristiwa Komunikatif (Communicative Event)}

Peristiwa komunikatif merupakan unsur yang memiliki tujuan komunikasi, topik umum yang sama, ragam bahasa yang sama, dan melibatkan partisipan yang sama. Selain itu memiliki kaidah-kaidah yang sama untuk berinteraksi dalam situasi yang sama. Sebuah peristiwa komunikatif terhenti apabila tidak ada aktivitas komunikasi, atau salah satu partisipan diam, tidak melakukan apapun. Terdapat beberapa komponen penting yang terdapat pada upacara pemberkatan pernikahan Khonghucu, yaitu:

(1) Setting, setting pada etnografi komunikasi mengacu pada tempat dan waktu terjadinya sebuah peristiwa. Sedangkan scene lebih mengacu pada suasana yang dialami partisipan. Pada UPPAK, tempat pelaksanaan upacara dilaksanakan di dua tempat, yakni di sekertariat MAKIN Provinsi Jambi dan di klenteng Tri Dharma Jambi, sedangkan waktu pelaksanaannya yaitu pada hari Sabtu, 11 November 2017. Pemilihan hari serta tanggal tersebut melalui kesepakatan keluarga kedua mempelai. Scene yang terlihat pada UPPAK ini adalah kebahagiaan karena telah dipersatukaanya dua insan yang berbeda, keharuan karena orang tua kedua mempelai menyadari bahwa anak-anak mereka telah 
menemukan pasangan hidupnya, dan khusu' yang terlihat pada saat beribadah di klenteng tanpa ada iring-iringan lonceng dan sebagainya.

(2) Partisipant atau pihak yang terlibat pada UPPAK ini adalah mempelai wanita, mempelai pria, keluarga kedua mempelai, seorang Zhiji, MC, dan penjaga klenteng. Keseluruhan partisipan tersebut memiliki peran yang berbeda-beda pada upacara pemberkatan tersebut. Seperti misalnya Zhiji berperan memimpin upacara pemberkatan, keluarga kedua mempelai berperan sebagai pengiring dan saksi pemberkatan, MC yang berperan mengarahkan jalannya upacara pemberkatan, serta kedua mempelai yang menjadi partisipan inti pada upacara pemberkatan pernikahan tersebut.

(3) Ends atau tujuan dari upacara pemberkatan tersebut adalah menyatukan dua manusia yang berbeda yang saling mengasihi untuk memulai kehidupan baru bersama pasangannya. Prosesi yang dijalani dari awal hingga akhir ritual dengan dibimbing oleh Zhiji menjadikan tujuan dari UPPAK dapat tercapai.

(4) Act Sequence merupakan urutan tindakan yang terdapat pada UPPAK. Urutan tindakan tersebut dimulai dari kedua mempelai memegang Hio dan di depan altar nabi Kongzi melakukan gerakan sebagai penghormatan, kemudian Zhiji mulai melakukan pemberkatan dengan tangan kedua mempelai berada diatas kitab suci umat Khonghucu mengucap janji. Setelah itu kedua mempelai meminta doa restu kepada kedua orang tua dan yang dituakan dalam keluarga.

Key yang mengacu pada nada, cara, dan semangat bagaimana pesan tersebut disampaikan. Penyampaian pesan tersebut dapat dilakukan dengan cara senang hati, serius, singkat, sombong, mengejek, dan sebagainya, atau juga menggunakan gerak tubuh dan isyarat. Pada UPPAK ini pesan disampaikan dengan cara senang hati, serius, menggunakan gerak tubuh atau isyarat.

(6) Instrument merupakan bentuk pesan yang disampaikan penutur kepada mitra tutur. Bentuk pesan tersebut dapat berupa lisan, tulisan, ataupun isyarat gerak tubuh. Pada penelitian ini, bentuk pesan yang disampaikan berupa pean berbal dan non-verbal. Berikut ini pesan verbal yang disampaikan oleh Zhiji yang berupa sabda Nabi Kongzi:

Nabi bersabda: "Camkanlah benar-benar hal pernikahan itu karena dial ah pohon segala Kesusilaan dan mencakup penghidupan manusia"

Maksud dari pesan verbal tersebut adalah, pernikahan diibaratkan sebagai sebuah pohon yang memiliki kehidupan yang dapat tumbuh dan berkembang. Begitupun 
pernikahan, penyatuan dua insan menjadi sepasang suami-isti juga memiliki kehidupoan bersama yang tumbuh dan berkembang seiring berjalannya waktu. Pernikahan baigai pohon yang memiliki berbagai cabang yang diibaratkan sebagai perilaku manusia dalam kehidupan. Pesan verbal kedua yang juga disampaikan oleh Zhiji adalah sebagai berikut:

“...Maka pernikahan itu tiada bermaksud menceraikan kamu dari ayah bunda dan keluargamu karena kamu telah membangun mahligai baru, melainkan dia bersifat menyatukan keluarga yang satu dengan yang lain, memupuk rasa persaudaraan yang luas diantara manusia, sehingga akhirnya terasakan bahwa di eтpat penjuru lautan seтиа umat bersaudara..."

Maksud dari tuturan tersebut adalah pernikahan bukan menjadi pemisah antara anak dan kedua orang tuanya, namun menyatukan dua keluarga. Potongan pesan “...akhirnya terasakan bahwa di empat penjuru lautan semua umat bersaudara...”, empat penjuru lautan adalah keluarga dari sepasang mempelai. Tuturan tersebut dimaksudkan bahwa dengan ikatan pernikahan maka dua keluarga yang digambarkan sebagai empat penjuru lautan dapat bersatu.

Selain pesan verbal, terdapat pesan non-verbal yang ditunjukkan dengan simbolsimbol digunakan pada upacara tersebut, dapat berupa Hio, Kitab suci agama Khonghucu, serta altar Nabi Kongzi. Hio digunakan sebagai alat untuk memanjatkan doa, asap yang berasal dari Hio dipercaya akan sampai ke atas, tempat Tian Maha Tinggi, Kitab suci digunakan sebagai lambang kesakralan dari agama dan prosesi upacara, altar nabi Kong zi melambangkan sebagai tempat atau sisi tempat Nabi Kongzi yang harus dihormati.

Norms merupakan aturan-aturan yang berlaku pada UPPAK. Undang-undang perkawinan di Indonesia telah diatur dalam Undang-undang Republik Indonesia No. 1 tahun 1974 tentang UU pernikahan, sedangkan tahun 1975 UU perkawinan Agama Khonghucu dikeluarkan. Beberapa hal yang harus diperhatikan tentang aturan pernikahan agama Khonghucu, diantaranya:

a. Pernikahan merupakan ikatan untuk meraih tujuan dalam janji suci dan dapat tercapai pernikahan yang suci dan murni.

b. Kedua calon mempelai wajib untuk mantap dalam iman dan dewasa dalam bertindak, berfikir, dan bertingkah laku.

c. Pada saat upacara pernikahan, keluarga dari kedua mempelai wajib hadir. Orang tua atau wali yang menghadiri pernikahan, menyalakan api altar sebagai wujud bahwa mereka merestui pernikahan kedua mempelai. 
(8) Genre atau tipe peristiwa pada suatu peristiwa dapat ditunjukkan dengan lelucon, salam, dongeng, doa, narasi, puisi, lagu, dan sebagainya. Genre yang terdapat pada pemberkatan pernikahan agama Khonghucu antara lain doa berupa permohonan, pujian, genre narasi berupa nasihat-nasihat kepada kedua mempelai yang akan menjalani kehiudan baru, genre salam berupa penghormatan kepada Nabi Kongzi.

Genre doa pada penelitian ini ditunjukkan ketika proses pemberkatan terlebih dahulu kedua mempelai dengan memegang hio (dupa yang dibakar), kemudian memberikan penghormatan kepada Nabi Kongzi (Tian) sebagai pembukaan atau salam sebelum memulai pemberkatan. Berikut ini doa berupa permohonan dan pujian yang terdapat pada UPPAK.

Data 3:

"Kehadirat Tian Yang Maha Besar, di tempat yang Maha Tinggi, dengan bimbingan Nabi Kongzi, Dipermuliakanlah! Shanzai.”

Maksud tuturan tersebut merupakan pujian yang dipanjatkan oleh umat Khonghucu sebelum memohon dan meminta sesuatu kepada nabi Kongzi. Tuturan tersebut berupa "Kehadirat Tian Yang Maha Besar, di tempat yang Maha Tinggi...”. Kita mengetahui bahwa Tuhan memiliki kekuasaan untuk melakukan segala sesuatu dan Tuhan Maha Besar serta Maha Tinggi, sehingga umat Khonghucu memuji keagungan Tuhannya yang bernama Nabi Khongzi. kita dapat melihat peristiwa bahwa umat Khonghucu menyebut Nabi Kongzi sebagai Tian (Tuhan), dan melalui salam tersebut kita dapat mengamati bahwa Nabi Kongzi berada di langit yang diidentifikasikan dengan frasa 'Maha Tinggi'. Ungkapan 'Shanzai' menunjukkan bahwa itu adalah ucapan puji syukur pada Tian.

Dalam tuturan “....dengan bimbingan Nabi Kongzi, Dipermuliakanlah! Shanzai.” Selain doa berupa pujian, umat Khonghucu juga memohon doa agar pemberkatan pernikahan yang dilaksanakan dapat berjalan lancar serta kehidupan pernikahan yang akan dilalui selalu diberikan bimbingan dari nabi Khongzi, sehingga kehidupan pernikahan menjadi tentram, bahagia, dan langgeng, serta diberikannya keturunan yang baik. Berikut ini doa berupa permohonan yang dipanjatkan oleh Zhiji pada UPPAK.

Data 4:

"Kini telah di Li Yuan kan pernikahan Daoqin berdua, mudah-mudahan sejahteralah penghidupanmu; dengan bimbingan Tian yang menjadi kekuatan susila kita dan tuntutan ajaran Nabi Kongzi..." 
Pada tuturan tersebut, kalimat permohonan dipanjatkan dalam suasana sakral dan khidmat. Perkawinan bersifat sakral bagi pemeluk agama Khonghucu. Prosesi perkawinan dan ritualnya tidak hanya sekedar dilihat sebagai acara seremonial. Akan tetapi di dalam acara tersebut terdapat pemberkatan perkawinan dan meminta rahmat dari Tuhan Yang Maha Esa (Tian), pemberkatan tersebut dalam agama Khonghucu disebut dengan Li Yuan. Kedua mempelai yang telah mendapatkan Li Yuan disebut dengan Dao Qin atau saudara di dalam Jalan Suci. Pada tuturan "Kini telah di Li Yuan kan pernikahan Daoqin berdua...", maka maksud dari tuturan tersebut adalah pada saat ritual, kedua mempelai telah mendapatkan Li Yuan (pemberkatan) dan menjadi sepasang suami-istri dalam ikatan pernikahan.

Dalam tuturan selanjutnya mengandung kalimat permohonan yang dipanjatkan kepada Nabi Kongzi “...mudah-mudahan sejahteralah penghidupanmu; dengan bimbingan Tian yang menjadi kekuatan susila kita dan tuntutan ajaran Nabi Kongzi...”. Maksud dari tuturan tersebut adalah sebuah permohonan setelah kedua mempelai mengikrarkan janji dalam ikatan pernikahan, kehidupan mereka selanjutnya menjadi sejahtera dengan tuntunan dan bimbingan dari Nabi Kongzi (Tian). Selain itu juga memohon bimbingan dalam berperilaku.

Data 5:

"Semoga dijauhkan kedua mempelai dari kelemahan, keluh gerutu, dijauhkan dari sesal penyalahan kepada sesama manusia, dapat tekun belajar dan menanggung kewajiban hidup dari tempat yang rendah ini dan terus maju menuju tinggi Jalan Suci”.

Tuturan pada data 3 memiliki maksud tentang permohonan agar setelah menikah dapat menjalani kehidupan dengan baik, dan dapat menghadapi berbagai rintangan dari dalam diri maupun lingkungan di sekitar hingga dapat meningkatkan keimanan yang sesuai dengan ajaran Nabi Kongzi. Peningkatan iman disampaikan dalam klausa 'Jalan Suci', sebuah tingkat keimanan yang didapatkan setelah melewati rintangan dari dalam diri dan lingkungan sekitar.

Genre selanjutnya berupa narasi yang berisi nasehat-nasehat kehidupan pernikahan yang akan dijalani oleh kedua mempelai. Berikut ini nasehat yang disampaikan oleh Zhiji kepada kedua mempelai: 
Data 6:

“...Oleh sebab itu mempelai berdua ... dan ... dapatkah kamu berdua merasakan betapa suci dan mulia maksud pernikahan seperti itu yang telah disabdakan oleh Nabi Kongzi ini? Dan bila kamu sudah dapat merasakan itu. Sediakah kamu berdua membina dirimu sehingga maksud suci pernikahan ini mewujud dalam penghidupanmu? (kedua mempelai menjawab: “SEDIA!').

Dengan kalimat tanya yang disampaikan oleh Zhiji, dimaksudkan untuk meyakinkan kedua mempelai bahwa pernikahan yang dijalani adalah bagian dari ibadah yang suci dan menjalani kehidupan selanjutnya dengan berpasrah kepada Tuhan. Apabila kedua mempelai yakin akan ikatan pernikahan, maka mempelai harus dapat mengamalkan pemahaman tentang ikatan pernikahan dalam kehidupan suami-istri. Nasehat berikutnya dituturkan oleh Zhiji dalam tuturan berikut:

Data 7:

"Camkanlah benar-benar hal pernikahan itu karena dialah pohon segala Kesusilaan dan mencakup penghidupan manusia”.

Dalam tuturan Zhiji tersebut memiliki maksud bahwa pernikahan diibaratkan sebagai pohon. Tumbuh dan berkembangnya pohon diibaratkan sebagai tumbuhnya perilaku diri dan perjalanan hidup manusia, maka dari itu manusia harus menghargai sebuah kehidupan.

\section{Tindak komunikasi}

Tindak komunikasi dalam upacara pemberkatan pernikahan Khonghucu dapat berupa fungsi interaksi tunggal, seperti, pernyataan, permohonan, perintah. Tindak komunikasi yang disampaikan dapat berupa komunikasi verbal maupun non verbal. Komunikasi verbal dapat berupa wejangan atau pesan yang biasanya disampaikan oleh kedua mempelai atau orang tua pada saat selesai pemberkatan.

Data 8:

"semoga kalian berbahagia."

Data 9:

"terimakasih telah membesarkan kami sampai sekarang ini."

Pada tuturan verbal seringkali didukung dengan komunikasi non verbal, contohnya pada penyampaian tuturan 8 dan 9 , kedua mempelai dan orangtua saling mengepalkan tangan di depan dada sebagai tanda saling menghormati. Tuturan data 8 disampaikan oleh 
kedua orang tua, sedangkan data 9 merupakan jawaban yang disampaikan oleh mempelai. Dalam upacara pemberkatan juga terdapat berbagai simbol sebagai lambang interaksi dalam situasi tersebut. Perwujudan simbol-simbol ini sudah dipahami bersama oleh umat Khonghucu yang mengikuti upacara tersebut. Contohnya dalam pernikahan terdapat air suci yang pada saat pemberkatan diminum oleh kedua mempelai, air ini merupakan symbol dari anugerah Tian dan leluhur. Hio (dupa) yang mengeluarkan asap sebagai symbol penyampaian pesan dan harapan kepada Tian untuk mendapatkan keberkahan. Beberapa sajian di depan altar, seperti buah-buahan dan kue-kue merupakan simbol sebagai bentuk rasa syukur terhadap Tian.

\section{Simpulan}

Penelitian ini merupakan penelitian yang mengkaji aktivitas komunikasi yang terjadi pada UPPAK. Aktivitas komunikasi pada APPAK dapat memberikan gambaran atau deskripsi dari acara adat tersebut. Berikut ini uraian kesimpulan dari penelitian acara adat UPPAK di Provinsi Jambi.

Pertama, Situasi komunkasi yang terjadi dalam upacara pemberkatan pernikahan Khonghucu berjalan dengan suasana sakral, memiliki unsur kebahagiaan, kegembiraan. Kedua, peristiwa komunikasi yang terjadi memiliki berbagai komponen penting yang menjelaskan urutan upacara pemberkatan dari awal hingga akhir, yaitu, penghormatan kepada Nabi Kongzi, penghormatan kepada leluhur, pengucapan janji pemberkatan yang dipimpin oleh zhiji dengan meletakkan tangan diatas kitab Khonghucu. Ketiga, tindak komunikasi pada upacara pemberkatan memiliki tindak komunikasi berupa wejangan yang disampaikan orang tua dan pernyataan yang memiliki maksud ucapan terimakasih disampaikan oleh kedua mempelai kedua mempelai.

\section{Daftar Pustaka}

Hymes, Dell. 1967. "Models of the Interaction of Language and Social Setting." Journal of Social Issues. https://doi.org/10.1111/j.1540-4560.1967.tb00572.x.

_. 1972. "4 The Use of Anthropology: Critical, Political, Personal.” In Reinventing Anthropology.

—. 2012. "Ways of Speaking." In Explorations in the Ethnography of Speaking. https://doi.org/10.1017/cbo9780511611810.029.

HYMES, DELL. 1964. "Introduction: Toward Ethnographies of Communication1." 
American Anthropologist. https://doi.org/10.1525/aa.1964.66.suppl_3.02a00010.

Kac, Michael B., John J. Gumperz, and Dell Hymes. 2006. "Directions in Sociolinguistics: The Ethnography of Communication.” Language. https://doi.org/10.2307/413167. Karsono, OMF. 2011. "Penggunaan Bahasa Oleh Anak Dalam Keluarga Pernikahan Antara Etnis Tionghoa Dan Suku Jawa." Zhurnal Eksperimental'noi i Teoreticheskoi Fiziki.

Kuswarno, Engkus. 2007. “Tradisi Fenomenologi Pada Penelitian Komunikasi Kualitatif Sebuah Pedoman Penelitian Dari Pengalaman Penelitian.” Sosiohumaniora2. https://doi.org/10.29313/mediator.v7i1.1218.

Saville-Troike, Muriel. 2008. The Ethnography of Communication: An Introduction: Third Edition. The Ethnography of Communication: An Introduction: Third Edition. https://doi.org/10.1002/9780470758373.

Sugiyono. 2016. "Memahami Penelitian Kualitatif." Bandung: Alfabeta. 